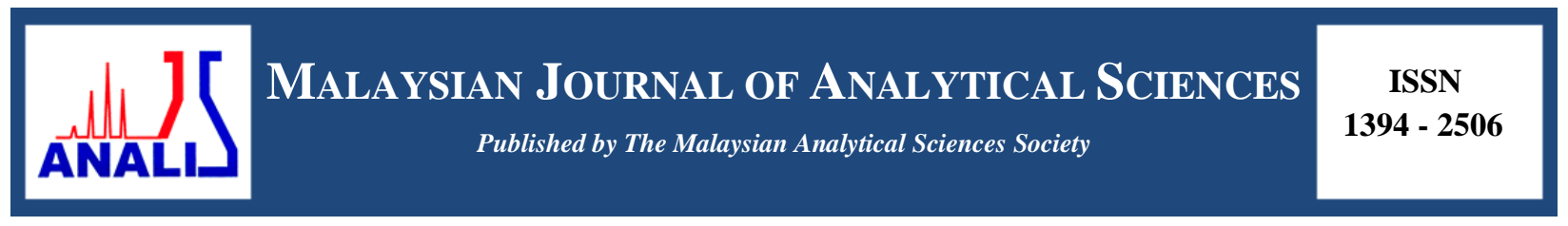

\title{
POLYVINYLPYRROLIDONE AS A NEW FLUORESCENT SENSOR FOR NITRATE ION
}

\author{
(Polivinilpirolidon Sebagai Sensor Pendafluor Baru Bagi Ion Nitrat) \\ Ing Hua Tang ${ }^{1}$, Rita Sundari ${ }^{2}$, Hendrik O. Lintang ${ }^{3}$, Leny Yuliati ${ }^{3 *}$ \\ ${ }^{1}$ Department of Chemistry, Faculty of Science, \\ Universiti Teknologi Malaysia, 81310 UTM Johor Bahru, Johor, Malaysia \\ ${ }^{2}$ The Research Center of Private Universities Coordination, 13360 Jakarta, Indonesia \\ ${ }^{3}$ Centre for Sustainable Nanomaterials, \\ Ibnu Sina Institute for Scientific and Industrial Research, \\ Universiti Teknologi Malaysia, 81310 UTM Johor Bahru, Johor, Malaysia \\ *Corresponding author: leny@ibnusina.utm.my
}

Received: 9 December 2014; Accepted: 9 October 2015

\begin{abstract}
In this study, non-conjugated polyvinylpyrrolidone(PVP) was investigated for the first time as the potential polymeric material to sense nitrate ions by fluorescence spectroscopy. The PVP was diluted into various concentrations $(3-10 \%)$ and they were used to sense the nitrate ions in different concentrations $(0.1-100 \mathrm{mM})$. The PVP showed two excitation peaks at 285 and $330 \mathrm{~nm}$ due to the presence of $\mathrm{C}=\mathrm{O}$ and $\mathrm{N}-\mathrm{C}$ groups, respectively. One strong emission at 400 or $408 \mathrm{~nm}$ was observed with the excitation at 285 or $330 \mathrm{~nm}$. The higher value of quenching constant at excitation wavelength of $285 \mathrm{~nm}$ indicated that $\mathrm{C}=\mathrm{O}$ site was more favored for $\mathrm{NO}_{3}{ }^{-}$ions sensing than the N-C site. The PVP 7\% gave the highest quenching constant; where the $\mathrm{K}_{\mathrm{Sv}}$ value was $9.89 \times 10^{-3}$ $\mathrm{mM}^{-1}$ and $2.44 \times 10^{-3} \mathrm{mM}^{-1}$ for excitation at 285 and $330 \mathrm{~nm}$, respectively. The sensing capability was evaluated in the presence of interference ions $\left(\mathrm{SO}_{4}{ }^{2-}, \mathrm{HCO}_{3}{ }^{-}, \mathrm{Cl}^{-}\right.$, and $\left.\mathrm{OH}^{-}\right)$. It was observed that the interference ions interacted strongly with the $\mathrm{C}=\mathrm{O}$, but weakly with the $\mathrm{N}-\mathrm{C}$. Therefore, in the presence of the interference ions, the PVP would be a potential fluorescent sensor when it is excited at $330 \mathrm{~nm}$.
\end{abstract}

Keywords: polyvinylpyrrolidone; fluorescent sensor; nitrate ions; quenching

\begin{abstract}
Abstrak
Dalam kajian ini, polivinilpirolidon (PVP) yang bersifat bukan konjugat dikaji untuk kali pertama sebagai bahan polimer yang berpotensi untuk mengesan ion nitrat dengan spektroskopi pendaflour. PVP dicairkan kepada kepekatan yang berlainan (3-10\%) dan digunakan untuk mengesan ion nitrat dalam kepekatan yang berbeza (0.1-100 mM). PVP menunjukkan dua puncak pengujaan pada 285 and $330 \mathrm{~nm}$ dengan kewujudan $\mathrm{C}=\mathrm{O}$ dan $\mathrm{N}-\mathrm{C}$ masing-masing. Satu puncak pemancaran yang tinggi pada 400 atau $408 \mathrm{~nm}$ diperolehi dengan pengujaan pada 285 atau $330 \mathrm{~nm}$. Pemalar pelidap kejutan dengan nilai yang lebih tinggi pada puncak pengujaan $285 \mathrm{~nm}$ menunjukkan bahawa tapak $\mathrm{C}=\mathrm{O}$ lebih cenderung untuk mengesan ion $\mathrm{NO}_{3}{ }^{-}$daripada tapak $\mathrm{N}-\mathrm{C}$. PVP 7\% memberi pemalar pelidap kejutan yang paling tinggi, dengan nilai $\mathrm{K}_{\mathrm{SV}} 9.89 \times 10^{-3} \mathrm{mM}^{-1}$ and $2.44 \times 10^{-3} \mathrm{mM}^{-1}$ untuk puncak pengujaan pada 285 dan $330 \mathrm{~nm}$ masing-masing. Kemampuan pengesanan dinilai dengan kehadiran ion gangguan $\left(\mathrm{SO}_{4}{ }^{2-}\right.$, $\mathrm{HCO}_{3}{ }^{-}, \mathrm{OH}^{-}$, and $\mathrm{Cl}^{-}$). Hasil kajian menunjukkan bahawa ion gangguan berinteraksi kuat dengan $\mathrm{C}=\mathrm{O}$, tetapi lemah dengan $\mathrm{N}-\mathrm{C}$. Oleh itu, dengan kehadiran ion gangguan, PVP berpotensi menjadi pendafluor sensor pada tapak pengujaan $330 \mathrm{~nm}$.
\end{abstract}

Kata kunci: polivinilpirolidon; pengesan pendaflour, ion nitrat, pelidap kejutan 


\section{Introduction}

Polymer consisting of repeating units of monomers is highly explored in various fields, owing to its non-toxicity [1], simple fabrication methodology and low cost [2, 3], large surface-to-volume ratio [4] and easy modification [5]. The conjugated polymers have received particular attentions with their wide applications in batteries [6], organic light emitting diodes [2, 4, 7], and sensor [2, 4-6, 8-10], due to their unique metallic and semiconducting properties [4] as well as the fluorescence properties [4, 5, 11]. On the other hand, the non-conjugated polymers are less explored and still poorly understood. To date, the non-conjugated polyvinylpyrrolidone (PVP) is mostly used as a passivator or a capping agent for semiconductor such as $\mathrm{ZnS}$ or $\mathrm{CdS}$, with the purpose to reduce the agglomeration and improve the optical property [12]. Some studies reported the application of the PVP as a sensor [14, 15]. Wang et al. reported that the PVP can be used as electrochemical sensor for acyclovir molecule [14], while Zhang et al. used PVP nanocomposite as a humidity sensor [16]. Since the PVP has been also reported to have photoluminescence property [15], it is worthy to study the possibility to use the non-conjugated PVP as the fluorescence sensor. To the best of our knowledge, there is no investigation on the application of the PVP as the fluorescence sensor. In this study, the PVP is used as the fluorescent sensor for detection of nitrate ions.

The nitrate ions are usually found in fertilizer for agriculture purpose. When the fertilizer is used excessively, the excess nitrate ions in the environmental water system will lead to algae blooms and eutrophication phenomena [1719]. On the other hand, nitrate ions that are consumed into body may cause methemoglobinemia and the nitrate ions might become the source of carcinogenic $n$-nitrosamines $[17,20]$. These are some of the reasons to monitor nitrate ions in the environment. Extensive studies have been explored to detect the nitrate ions using different techniques, such as ion chromatography [18], capillary electrophoresis [3, 20], electrochemical [3, 21-24], and fluorescence spectroscopy [17]. However, the detection limit and linear detection range of existing nitrate ion sensor are still not in satisfactory level [21], and this urges researchers to develop better nitrate sensors.

In this study, the feasibility to develop PVP fluorescence sensor for nitrate ions was examined using different concentrations of PVP and nitrate ions. The favorable sites to interact with the nitrate ions were discussed based on the quenching phenomena. Besides, the selectivity of the PVP to the nitrate ions was evaluated in the presence of other interference ions such as $\mathrm{SO}_{4}{ }^{2-}, \mathrm{HCO}_{3}{ }^{-}, \mathrm{Cl}^{-}$, and $\mathrm{OH}^{-}$.

\section{Materials}

\section{Materials and Methods}

The PVP solution (K 60, Aldrich, $\mathrm{Mw} \approx 160000,45 \%$ in water), sodium nitrate $\left(\mathrm{NaNO}_{3}, \mathrm{Merck}, 99.5 \%\right)$, sodium sulphate $\left(\mathrm{Na}_{2} \mathrm{SO}_{4}\right.$, Fisher Scientific, > 99\%), sodium hydrogen carbonate $\left(\mathrm{NaHCO}_{3}\right.$, Fisher Scientific, $\left.99 \%\right)$, sodium chloride ( $\mathrm{NaCl}$, Fisher Chemical, 100.1\%), and sodium hydroxide (NaOH, QRëC, 99\%) were used as-received without any treatments.

\section{Preparation of PVP}

A series of various concentrations of PVP was prepared from the PVP (K 60) by dilution method using deionized water. The prepared solution was shown as $\mathrm{x} \%$ of PVP, where $\mathrm{x}$ showed the concentrations of the PVP $(3,5,7$, and $10 \%)$.

\section{Fluorescence, quenching and selectivity test}

The fluorescence property and sensing capability of the PVP solutions for detection of nitrate ions were studied using a fluorescence spectroscopy (JASCO, FP-8500) at room temperature. The excitation spectra of the PVP solutions were monitored at emission wavelengths of 400 or $408 \mathrm{~nm}$, while the emission spectra were monitored at the excitation wavelengths of 285 or $330 \mathrm{~nm}$. For quenching test, the PVP solution was exposed to various concentrations of nitrate ions $(0.1-100 \mathrm{mM})$ and the interaction between the emission sites and the nitrate ions was measured. The sensing capability of the PVP was evaluated in the presence of interference ions $\left(\mathrm{SO}_{4}{ }^{2-}, \mathrm{HCO}_{3}{ }^{-}, \mathrm{Cl}^{-}\right.$, and $\left.\mathrm{OH}^{-}\right)$. The concentration for the nitrate ions and each interference ions was fixed at the concentration of 100 $\mathrm{mM}$. 


\section{Fluorescence property of PVP}

\section{Results and Discussion}

The fluorescence property of the PVP solution was studied by investigating its excitation and emission sites. As shown in Figure 1, all the prepared PVP (3-10\%) exhibited two excitation sites at 285 and $330 \mathrm{~nm}$ and one emission site at 400 or $408 \mathrm{~nm}$ when they were excited at 285 or $330 \mathrm{~nm}$. The excitation at $285 \mathrm{~nm}$ would be attributed to the presence of $\mathrm{C}=\mathrm{O}$, while the excitation at $330 \mathrm{~nm}$ would be corresponded to the presence of N-C in the PVP, similar to the reported one [12]. It was clear that the excitation and emission intensity increased with the increase of the PVP concentrations. The increased intensities were reasonable since they indicated the increased amount of excitation and emission sites of the PVP with the increase of the concentrations. Figure 1 also showed that the intensity of $\mathrm{N}-\mathrm{C}$ sites was higher than that of $\mathrm{C}=\mathrm{O}$ sites, suggesting that the $\mathrm{N}-\mathrm{C}$ sites would be the main excitation sites in the PVP and the $\mathrm{N}-\mathrm{C}$ sites showed greater fluorescence quantum yield than the $\mathrm{C}=\mathrm{O}$ site [25].
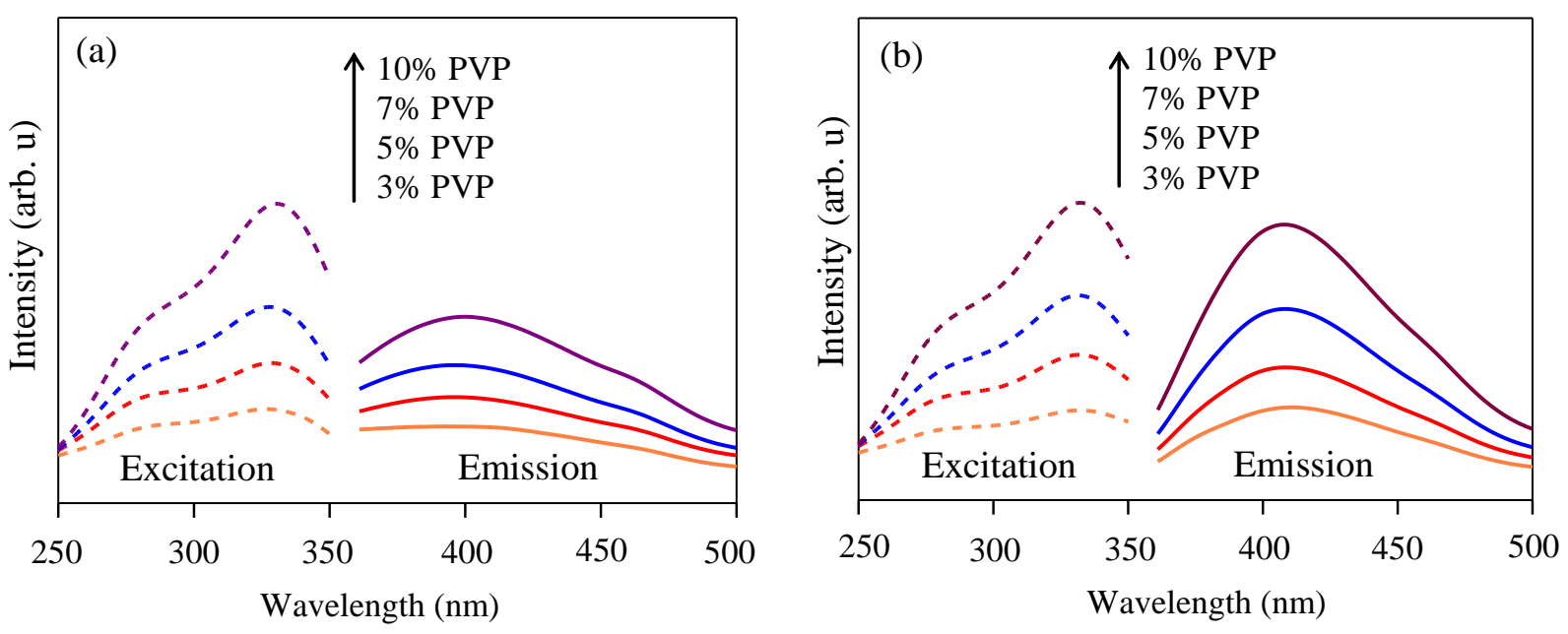

Figure 1. Excitation and emission spectra for 3,5,7 and $10 \%$ of $\mathrm{PVP}$ at (a) $\mathrm{C}=\mathrm{O}$ and (b) $\mathrm{N}-\mathrm{C}$ sensing sites

\section{Quenching tests}

In order to investigate the performance of the PVP to sense the nitrate ions, the interaction between emission sites and the nitrate ions were evaluated by quenching effect study. The quenching tests were evaluated by monitoring the changes in the emission intensity after addition of various concentrations of nitrate ions (0.1-100 mM). The emission spectra were monitored at two different excitation wavelengths, which were $285 \mathrm{~nm}$ and $330 \mathrm{~nm}$. All the $3-10 \%$ of PVP showed similar results to each other, in which the emission intensities of the PVP were quenched after addition of the nitrate ions. The results of the quenching tests for the 7\% of PVP are shown in Figure 2. The decrease in the emission intensity increased with the increase of nitrate ions concentrations for both emission sites, which were $\mathrm{C}=\mathrm{O}$ and $\mathrm{N}-\mathrm{C}$ sites. Among the prepared PVP, the 7\% of PVP showed the most quenched intensity, suggesting that the 7\% of PVP showed the strongest interaction with the nitrate ions (not shown).

As shown in Figure 2, quenching effects were observed on both $\mathrm{C}=\mathrm{O}$ and $\mathrm{N}-\mathrm{C}$ emission sites, suggesting that there were certain interactions between both the emission sites and the nitrate ions. Due to the difference of the charge between the emission sites and the nitrate ions, the most possible interactions between PVP and nitrate ions would be electrostatic interactions. Similar interactions have been proposed for the interactions between nitrates and polypyrrole [22], nitro-containing compounds with polymers [11, 26, 27]. In the presence of the same concentration of nitrate ions, especially at high concentrations, it was obviously observed that the $\mathrm{C}=\mathrm{O}$ sites were more quenched than the $\mathrm{N}-\mathrm{C}$ sites. This might be due to the reason that at each $\mathrm{C}=\mathrm{O}$ can interact with more than one nitrate ions simultaneously and this can be more intense at higher concentration of nitrate ions. Moreover, a slight red shift in 
the emission peak wavelength at high concentration of nitrate ions were also observed, suggesting that there was loss of energy through vibrational relation or internal conversion phenomena when the PVP interacted with nitrate ions [25].
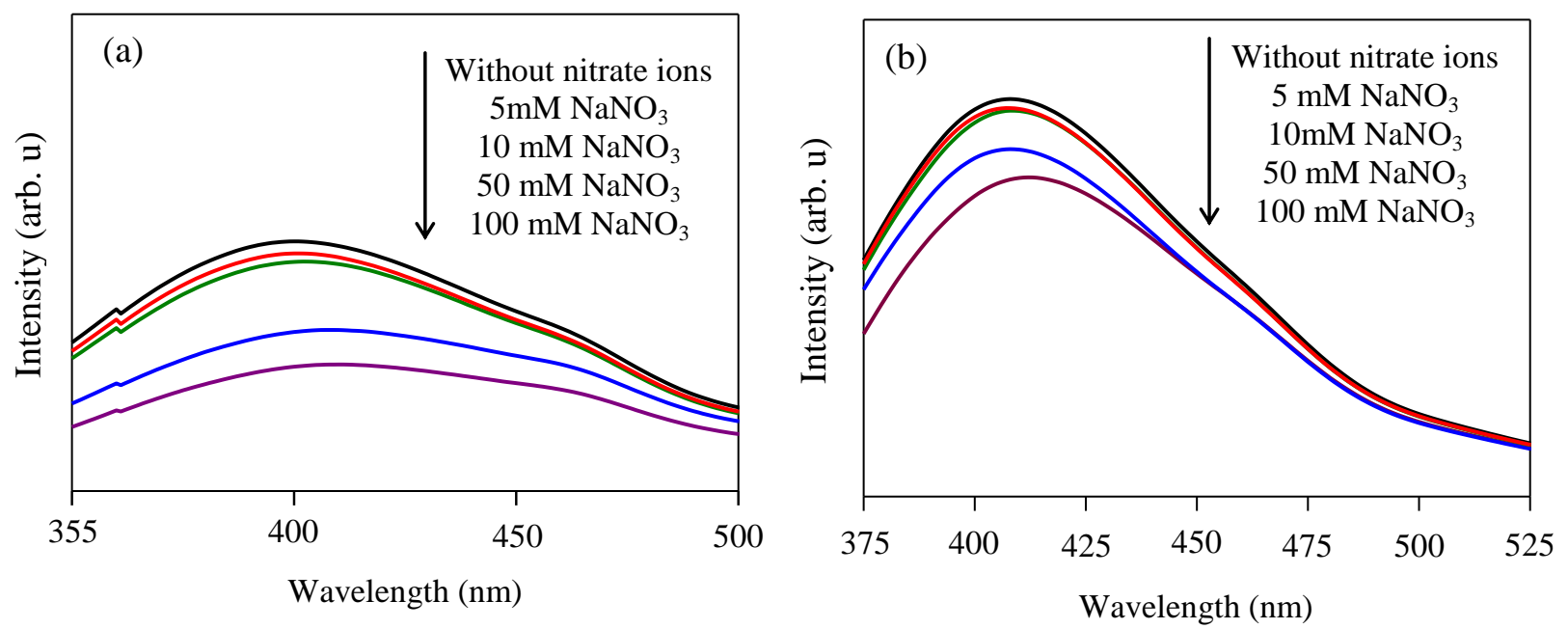

Figure 2. Emission spectra of 7\% PVP with the absence and presence of nitrate ions in the 5-100 mM range for $\mathrm{C}=\mathrm{O}$ sites and $\mathrm{N}-\mathrm{C}$ sites, monitored at excitation wavelength of (a) $285 \mathrm{~nm}$ and (b) $330 \mathrm{~nm}$

The interaction between the emission sites and nitrate ions can be evaluated by using the Stern-Volmer plot. When the illumination intensity and the amount of PVP are maintained to be constant, the relative emission intensity can be expressed as a function of the nitrate ions concentrations, according to the Stern-Volmer equation (Eq. 1),

$$
\frac{I_{o}}{I}=K_{s v}[Q]+1
$$

where $I_{o}$ and $I$ are fluorescence intensities obtained in the absence and presence of nitrate ions, respectively, $Q$ is the concentration of nitrate ions, and $K_{s v}$ is the Stern-Volmer quenching constant.

Figure 3 shows the Stern-Volmer plots for the 7\% of PVP. The plots were linear for both emission sites, suggesting that both $\mathrm{C}=\mathrm{O}$ and $\mathrm{N}-\mathrm{C}$ sites acted as the sensing sites for the nitrate ions. The slopes of the Stern-Volmer plots represented the quenching constant $\left(K_{S V}\right)$, which values were $9.89 \times 10^{-3} \mathrm{mM}^{-1}$ and $2.44 \times 10^{-3} \mathrm{mM}^{-1}$ for C=O and $\mathrm{N}-\mathrm{C}$ sites, respectively. The higher value of the $K_{S V}$ for the $\mathrm{C}=\mathrm{O}$ sites than that for the $\mathrm{N}-\mathrm{C}$ sites indicated that the $\mathrm{C}=$ sites were more favorable to sense nitrate ions than the $\mathrm{N}-\mathrm{C}$ sites. This might be due to the reasons that the $\mathrm{C}=\mathrm{O}$ sites have higher polarity than the N-C sites, but with less steric hindrance effect. The higher $K_{S V}$ values obtained on the $\mathrm{C}=\mathrm{O}$ sites can be observed as well on other PVP with various concentrations, as can be seen in Figure 4 . It can be clearly shown that the $K_{S V}$ values increased with the PVP concentrations up to $7 \%$, but decreased when the PVP concentration was $10 \%$. This result clearly suggested that $7 \%$ of PVP was an optimum concentration to get the highest quenching efficiency.

\section{Selectivity Tests}

The sensing performance of $7 \%$ of PVP towards nitrate ions was evaluated with the co-existence of interference ions. The interference ions used in current study were $\mathrm{SO}_{4}{ }^{2-}, \mathrm{HCO}_{3}{ }^{-}, \mathrm{Cl}^{-}$and $\mathrm{OH}^{-}$.The extent of interference was determined according to the equation below (Eq. 2): 


$$
E=\frac{I_{o}-I}{I_{o}} \times 100 \%
$$

where $I_{o}$ and $I$ show the fluorescence emission intensity for the 7\% of PVP with the presence of nitrate ions only and the presence of both nitrate and interference ions, respectively. The high value of the extent of interference suggested the high interference effect of the ions towards the performance of the 7\% PVP for detection of the nitrate ions.

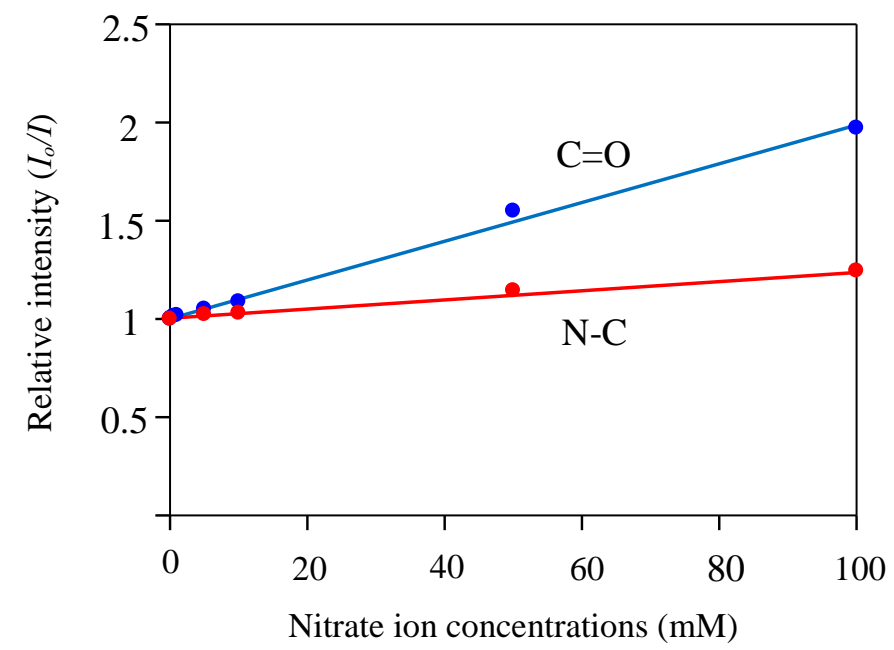

Figure 3. Linear Stern-Volmer plots for 7\% PVP at C=O $(\bullet)$ and $\mathrm{N}-\mathrm{C}(\bullet)$

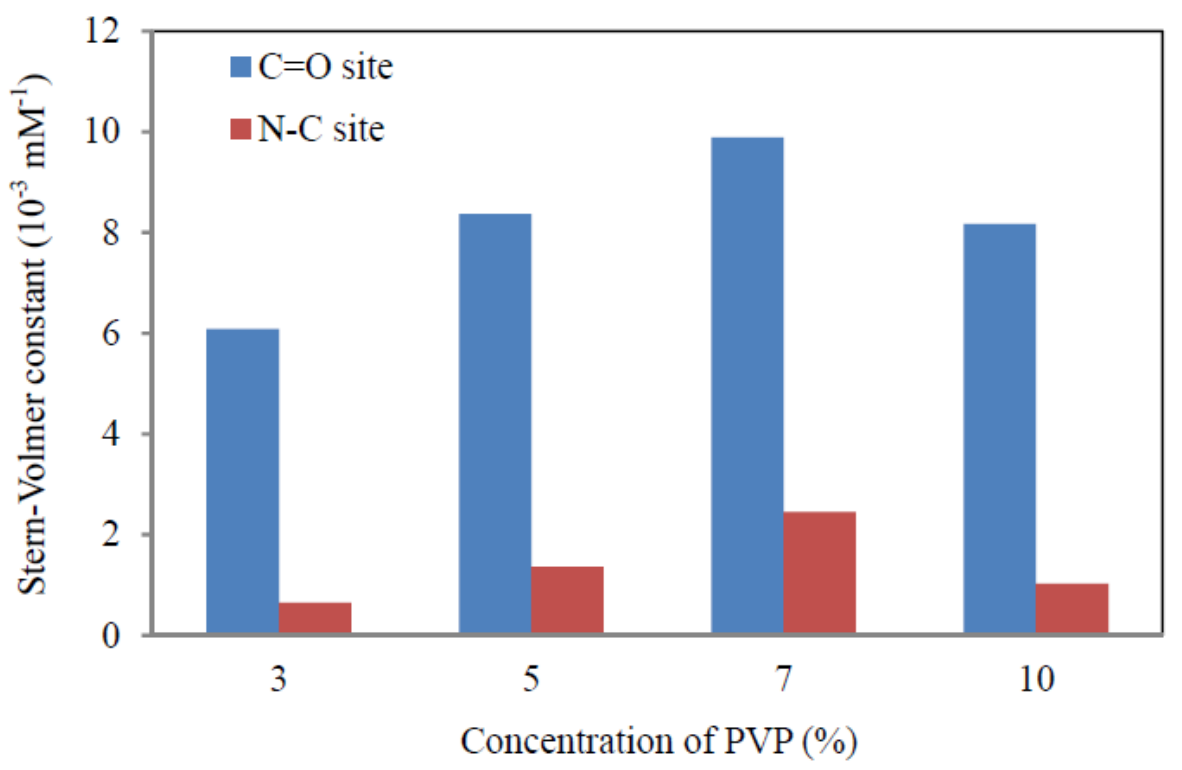

Figure 4. Stern-Volmer constants for nitrate ions detection on PVP with various concentrations for both $\mathrm{C}=\mathrm{O}$ and $\mathrm{N}-\mathrm{C}$ sites 
The extent of interference for each interference ion was shown in Figure 5. As for the $\mathrm{C}=\mathrm{O}$ sites, the presence of $\mathrm{SO}_{4}{ }^{2-}, \mathrm{HCO}_{3}{ }^{-}, \mathrm{Cl}^{-}$, and $\mathrm{OH}^{-}$ions gave extent of interferences, which values of $25,12,4$, and $47 \%$, respectively. This result suggested that the detection of nitrate ions by $\mathrm{C}=\mathrm{O}$ sites were mostly influenced by $\mathrm{OH}^{-}$, followed by $\mathrm{SO}_{4}{ }^{2-}$, $\mathrm{HCO}_{3}{ }^{-}$, and $\mathrm{Cl}^{-}$ions. The high interference effect from $\mathrm{OH}^{-}$would be caused by the small size and polarity of $\mathrm{OH}^{-}$ ions [27]. Therefore, the 7\% of PVP would not be suitable to detect nitrate ions in the presence of $\mathrm{OH}^{-}$ions. On the other hand, even though the co-existence of polyatom anions such as $\mathrm{SO}_{4}{ }^{2-}$ and $\mathrm{HCO}_{3}{ }^{-}$resulted in lower effect than the $\mathrm{OH}^{-}$, the $\mathrm{C}=\mathrm{O}$ sites competitively interacted with $\mathrm{SO}_{4}{ }^{2-}$ and $\mathrm{HCO}_{3}{ }^{-}$. Therefore, the sensing performance would be affected in the presence of these ions. It is worthy noted that the $\mathrm{C}=\mathrm{O}$ sites showed much less interaction with $\mathrm{Cl}^{-}$, suggesting that the $\mathrm{C}=\mathrm{O}$ sites still could be used to detect the nitrate ions even in the presence of $\mathrm{Cl}^{-}$ions.

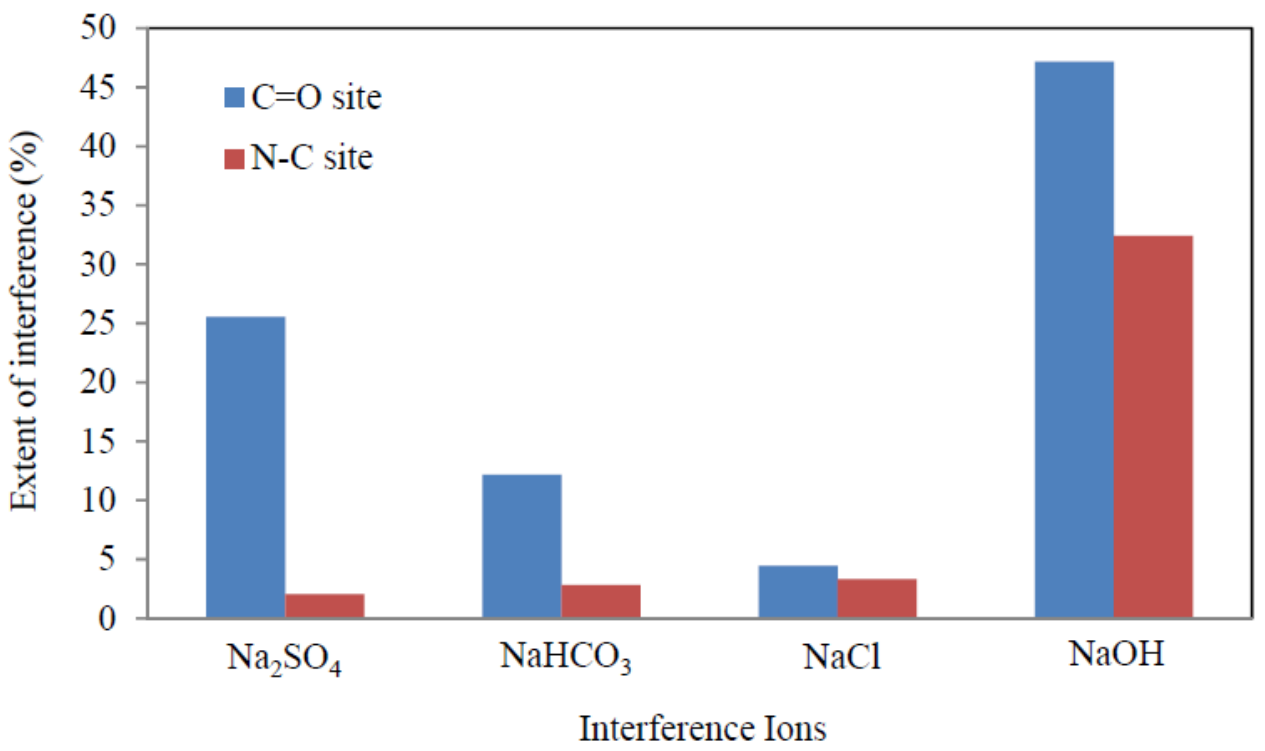

Figure 5. Extent of interferences of ions towards nitrate ions detection on 7\% PVP

As for the N-C sites, the presence of $\mathrm{SO}_{4}{ }^{2-}, \mathrm{HCO}_{3}{ }^{-}, \mathrm{Cl}^{-}$, and $\mathrm{OH}^{-}$ions gave extent of interferences, which values of $2,3,3$, and $32 \%$, respectively. Similar to the $\mathrm{C}=\mathrm{O}$ sensing sites, the $\mathrm{N}-\mathrm{C}$ sites were found to be affected by the presence of $\mathrm{OH}^{-}$. Different from the $\mathrm{C}=\mathrm{O}$ sites, the performance of the nitrate sensing on the $\mathrm{N}-\mathrm{C}$ sites were not much influenced by $\mathrm{SO}_{4}{ }^{2-}, \mathrm{HCO}_{3}{ }^{-}$, or $\mathrm{Cl}^{-}$ions. These results suggested that the $\mathrm{N}-\mathrm{C}$ sensing sites still can selectively interact with nitrate ions in the presence of these interfering ions.

\section{Conclusion}

The PVP showed two excitation peaks at 285 and $330 \mathrm{~nm}$ and one emission peak at 400 or $408 \mathrm{~nm}$ when excited at 285 and $330 \mathrm{~nm}$. Among the prepared PVP, 7\% of PVP showed the highest quenching constants toward the nitrate ions. The linear Stern-Volmer plot was observed, suggesting that the PVP can be used as a potential fluorescence sensor for nitrate ions. The $\mathrm{C}=\mathrm{O}$ sites were found to show much stronger interactions with nitrate ions (four times higher) than the $\mathrm{N}-\mathrm{C}$ sites, suggesting that the $\mathrm{C}=\mathrm{O}$ sites were more favorable to sense the nitrate ions. The presence of interference ions were found to affect the fluorescence sensing of nitrate ions differently. As for $\mathrm{C}=\mathrm{O}$ sites, it can still be used to sense nitrate ions in the presence of $\mathrm{Cl}^{-}$ions. On the other hand, the $\mathrm{N}-\mathrm{C}$ sites can selectively sense the nitrate ions in the presence of $\mathrm{SO}_{4}{ }^{2-}, \mathrm{HCO}_{3}{ }^{-}$, and $\mathrm{Cl}^{-}$ions. 


\section{Acknowledgement}

The work was financially supported by the Ministry of Higher Education (MOHE, Malaysia) and the Universiti Teknologi Malaysia (UTM, Malaysia) through a Tier-1 Research University Grant (cost center code: Q.J130000.2509.06H66). I.H.T acknowledges the support of MyBrain MyPhd scholarship.

\section{References}

1. Bourlinos, A. B., Georgakilas, V., Zboril, R., Steriotis, T. A., Stubos, A. K. and Trapalis, C. (2009). Aqueousphase exfoliation of graphite in the presence of polyvinylpyrrolidone for the water-soluble graphenes. Solid State Communications, 149 (47-48): 2172-2176.

2. Harsányi, G. (2000). Polymer films in sensor applications: A review of present uses and future possibilities. Emerald Insight, 20 (2): 98-105.

3. Chen, G., Lin, Y. and Wang, J. (2006). Monitoring environmental pollutants by microchip capillary electrophoresis with electrochemical detection. Talanta, 68 (3): 497-503.

4. Ozaydin-Ince, G., Coclite, A. M. and Gleason, K. K. (2012). CVD of polymeric thin films: applications in sensors, biotechnology, microelectronics/organic electronics, microfluidics, MEMS, composites and membranes. Report on Progress in Physics, 75 (1): 016501

5. Fan, L-J., Zhang, Y. and Jones, W. E. (2005). Design and synthesis of fluorescence "Turn-on" chemosensors based on photoinduced electron transfer in conjugated polymers. Macromolecules, 38 (7): 2844-2849.

6. Gangopadhyay, R. and De, A. (2000). Conducting polymer nanocomposites: a brief overview. Chemistry of Materials, 12 (3): 608-622.

7. Heeger, A. J. (2001). Semiconducting and metallic polymers: The fourth generation of polymeric materials. Journal of Physical Chemistry B, 105 (36): 8475-8491.

8. Vijayakumar, N., Subramanian, E. and Padiyan, D. P. (2012). Conducting polyaniline blends with the soft template poly(vinyl pyrrolidone) and their chemosensor application. International Journal of Polymer Materials, 61 (11): 847-863.

9. Akinyeye R. O., Michira, I., Sekota, M., Ahmed, A. A., Tito, D., Baker, P. G. L., Brett, C. M. A., Kalaji, M. and Iwuoha, E. (2007). Electrochemical synthesis and characterization of 1,2-naphthaquinone-4-sulfonic acid doped polypyrrole. Electroanalysis, 19 (2-3): 303-309.

10. Liu, S., Wang, L., Luo, Y., Tian, J., Li, H. and Sun, X. (2011). Polyaniline nanofibres for fluorescent nucleic acid detection. Nanoscale, 3 (3): 967-969.

11. Sam, M. S., Lintang, H. O., Sanagi, M. M., Lee, S. L. and Yuliati, L. (2014). Mesoporous carbon nitride for adsorption and fluorescence sensor of $n$-nitrosopyrrolidone. Spectrochimica Acta Part A: Molecular and Biomolecular Spectroscopy, 124: 357-364.

12. Minh, T. T., Van, B. P., Van, T. D. and Thi, H. N. (2013). The optical properties and energy transition process in nanocomposite of polyvinyl-pyrrolidone polymer and Mn-doped ZnS. Optical and Quantum Electronics, 45 (2): 147-159.

13. Nishizawa, S., Kato, Y. and Teramae, N. (1999). Fluorescence sensing of anions via intramolecular excimer formation in a pyrophosphate-induced self-assembly of a pyrene-functionalized guanidium receptor. Journal of American Chemical Society, 121 (40): 9463-9464.

14. Wang, P., Gan, T., Zhang, J., Luo, J. and Zhang, S. (2013). Polyvinylpyrrolidone-enhanced electrochemical oxidation and detection of acyclovir. Journal of Molecular Liquids, 177:129-132.

15. Thi, T. M., Tinh, L. V., Van, B. H., Ben, P. V. and Trung, V. Q. (2012). The effect of polyvinylpyrrolidone on the optical properties of the Ni-doped $\mathrm{ZnS}$ nanocrystalline thin films synthesized by chemical method. Journal of Nanomaterials, 2012:1-8.

16. Zhang, J., Shen, G., Wang, W., Zhou, X. and Guo, S. (2010). Individual nanocomposite sheets of chemically reduced graphene oxide and poly(n-vinyl pyrrolidone): Preparation and humidity sensing characteristics. Journal of Materials Chemistry, 20 (48): 10824-10828.

17. Taylor, C. J., Bain, L. A., Richardson, D. J., Spiro, S. and Russell, D. A. (2004). Construction of a whole-cell gene reporter for the fluorescent bioassay of nitrate. Analytical Biochemistry, 328 (1): 60-66.

18. Ito, K., Takayama, Y., Makabe, N., Mitsui, R. and Hirokawa, T. (2005). Ion chromatography for determination of nitrite and nitrate in seawater using Monolithic ODS columns, Journal of Chromatography A, 1083(1-2): 6367. 
19. Smil, V. (1997). Global population and the nitrogen cycle. Scientific American, 277: 76-81.

20. Moorcroft, M. J., Davis, J. and Compton, R. G. (2001). Detection and determination of nitrate and nitrite: A review. Talanta, 54 (5): 785-803.

21. Tu, X., Gao, Y., Yue, R., Lu, Q., Zhou, Y. and Lu, Z. (2012). An amperometric nitrate sensor based on wellaligned cone-shaped polypyrrole-nanorods. Analytical Methods, 4 (12): 4182-4186.

22. Bendikov, T. A. and Harmon, T. C. (2005). A sensitive nitrate ion-selective electrode from a pencil lead. An analytical laboratory experiment. Journal of Chemical Education, 82 (3): 439-441.

23. Jang, A., Zou, Z., Lee, K. K., Ahn, C. H. and Bishop, P. L. (2010). Potentiometric and voltammetric polymer lab chip sensors for determination of nitrate, $\mathrm{pH}$, and $\mathrm{Cd}(\mathrm{II})$ in Water. Talanta, 83 (1): 1-8.

24. Adeloju, S. B. and Sohail, M. (2011). Polypyrrole-based bilayer nitrate amperometric biosensor with an integrated permselective poly-ortho-phenylenediamine layer for exclusion of inorganic interferences. Biosensors and Bioelectronics, 26 (11): 4270-4275.

25. Lakowicz, J. R. (2006). Principles of Fluorescence Spectroscopy. Springer: New York. $3^{\text {rd }}$ edition.

26. Long, Y., Chen, H., Yang, Y., Wang, H., Yang, Y., Li, N., Li, K., Pei, J. and Liu, F. (2009). Electrospun nanofibrous film doped with a conjugated polymer for DNT fluorescence sensor. Macromolecules, 42 (17): 6501-6509.

27. Yang, J.-S. and Swager, T. M. (1998). Fluorescent porous polymer films as TNT chemosensors: Electronic and structural effects. Journal of American Chemical Society, 120 (46): 11864-11873.

28. Shen, G., Wang, W., Zhou, X. and Guo, S. (2010). Individual nanocomposite sheets of chemically reduced graphene oxide and poly(n-vinyl pyrrolidone): Preparation and humidity sensing characteristics. Journal of Materials Chemistry, 20 (48): 10824-10828.

29. Taylor, C. J., Bain, L. A., Richardson, D. J., Spiro, S. and Russell, D. A. (2004). Construction of a whole-cell gene reporter for the fluorescent bioassay of nitrate. Analytical Biochemistry, 328 (1): 60-66.

30. Ito, K., Takayama, Y., Makabe, N., Mitsui, R. and Hirokawa, T. (2005). Ion chromatography for determination of nitrite and nitrate in seawater using Monolithic ODS columns, Journal of Chromatography A, 1083(1-2): 6367.

31. Smil, V. (1997). Global population and the nitrogen cycle. Scientific American, 277: 76-81.

32. Moorcroft, M. J., Davis, J. and Compton, R. G. (2001). Detection and determination of nitrate and nitrite: A review. Talanta, 54 (5): 785-803.

33. Tu, X., Gao, Y., Yue, R., Lu, Q., Zhou, Y. and Lu, Z. (2012). An amperometric nitrate sensor based on wellaligned cone-shaped polypyrrole-nanorods. Analytical Methods, 4 (12): 4182-4186.

34. Bendikov, T. A. and Harmon, T. C. (2005). A sensitive nitrate ion-selective electrode from a pencil lead. An analytical laboratory experiment. Journal of Chemical Education, 82 (3): 439-441.

35. Jang, A., Zou, Z., Lee, K. K., Ahn, C. H. and Bishop, P. L. (2010). Potentiometric and voltammetric polymer lab chip sensors for determination of nitrate, $\mathrm{pH}$, and $\mathrm{Cd}(\mathrm{II})$ in Water. Talanta, 83 (1): 1-8.

36. Adeloju, S. B. and Sohail, M. (2011). Polypyrrole-based bilayer nitrate amperometric biosensor with an integrated permselective poly-ortho-phenylenediamine layer for exclusion of inorganic interferences. Biosensors and Bioelectronics, 26 (11): 4270-4275.

37. Lakowicz, J. R. (2006). Principles of Fluorescence Spectroscopy. Springer: New York. $3^{\text {rd }}$ edition.

38. Long, Y., Chen, H., Yang, Y., Wang, H., Yang, Y., Li, N., Li, K., Pei, J. and Liu, F. (2009). Electrospun nanofibrous film doped with a conjugated polymer for DNT fluorescence sensor. Macromolecules, 42 (17): 6501-6509.

39. Yang, J.-S. and Swager, T. M. (1998). Fluorescent porous polymer films as TNT chemosensors: Electronic and structural effects. Journal of American Chemical Society, 120 (46): 11864-11873. 